\title{
Conservation and Innovation Development to Some Ancient Dialects of Today Albanian
}

\author{
Dr. Edlira Troplini (Abdurahmani)
}

Lecturer and Researcher in Sociolinguistics Email: edlira.troplini@yahoo.com

\section{Doi:10.5901/ajis.2014.v3n6p518}

\section{Abstract}

This paper will deal with the analysis of some typical early occurrences of a common physiognomy of some ancient Albanian dialects. It is not the first time that we deal with their study, but we always come forward new arguments in defense of the thesis, for the perception of conservative phenomena of these idioms before they disappear. Specifically we present some valuable generalizations and new analysis related thereto. On the other hand, will be served also some new arguments regarding phenomena mentioned for the first of us, and some other phenomena in our view that carry with them the shadow of doubt. Will also address the various out linguistic factors that have driven their preservative character. This is a qualitative paper based on direct interviews of the older generation, without compromising the younger generation, but the given examples specifically belong to the older generation dialect by approaching them with texts or documents of old Albanian, moving from one direction to another. This is done for the sole purpose, not merely the perception of conservation phenomena of these idioms before they disappear, but in order that the latter may serve as motivation for finding new arguments related thereto, or for the emergence of previously unexplored phenomena. We are dealing with a sociolinguistic work that is the fruit of a synchronic and diachronic analysis. Results of this study become evidence of linkages that exist between Sociolinguistics and history of the Albanian language, conservatism and innovation, thus preserving and continuing or the ongoing renovation from the other side. Idioms that have received in the survey are indicative of an early bilingualism by which time even starts the chronology of this phenomenon.

Keywords: Sociolinguistics- History of the Albanian language, conservation-innovation, archaic dialects.

\section{Introduction}

Languages in general vary from day to day, despite stiff resistance featuring their standard. The variation, the engine of evolution of a language, in most cases is motivated by the development and the progress, so recently and always arises the need for a more developed standard. The languages situation today is diverse. Languages which have developed rapidly and languages because of various reasons (linguistic and outside linguistic) do not follow the same rate; have languages that differ towards worldwide development axis and those type of languages that exhibit less change. After this statement, the reader is right to want to ask: what is the status of the Albanian language?

In Albania, day by day, efforts are being made by dialectologists for a record of the speeches before they disappear. The alarm has been activated whenever the dialect which is considered archaic.

On the other hand, the effort to a suitable standard remains one of the most hot problems today.

Even in terms of variants of the idioms occurs the same process. Some dialects run much faster towards the standard and some other not. Dialectal words tend to become bound occurrences of standard and blend in it (Gjinari 1985: 45). The researcher Gjinari reaches this conclusion for all dialects. But, not for any idiom case occurs the same situation. Although most dialects of Albanian remote terminal or ancient dialects (such as idioms that have taken into consideration) tend towards innovation (supported by external factors such as in the case of our idioms, the bilingualism phenomenon), again the pace of the change and the flood from the standard appear slower.

They still retain obsolete phenomenon, but important. These old phenomenon as also are the phenomena found in the documents before the written Albanian, still used today in everyday discourse of Arbëresh, Arvanites, the Cham and think that this point constitutes the key issue that we will treat. 


\section{Method}

\subsection{Participants}

We recently had in the survey the diaspora dialects, such as the Arbëresh dialect, the dialect of Arvanites, the dialect of Chameria (an Albanian diaspora dispersed throughout the state), and sometimes turning attention to the first documents of written Albanian.

As mentioned above, this is a quality paper and the method we used is the method of interviewing. We also used direct research in old texts of these languages, as well as analysis of transcripts of researchers in voice, if it's early documents. Often we take for granted these tests and sometimes are not agreeing with them, if it was necessary.

\subsection{Materials}

Specifically, during the analysis we have considered the dialect of Buzuku (Missal - the first document of the written Albanian, the analysis of this work by S. Riza); the dialect of Chameria (early Cham dialect extended by Q. Haxhihasani in dialectological terms, the today Cham dialect extended by E. Troplini, a.2012); dialect of Arvanites (Reinhold's texts, analyzed by A. Klosi); the dialect of Arbëresh (various Arbëresh villages texts and analysis for these dialects of different Arbëresh researchers served by Gj. Shkurtaj).

\section{Results}

Researchers have always concluded that through old phenomena can be achieved in ensuring recognition of Albanian development stages and theoretically claimed that through them can be rebuilt its still unknown phases. Consequently, these phenomena help to clarify the history of the Albanian language, which for lack of arguments is still unclear. This is exactly why further research of these phenomena worth Albanian language. On the other hand, are exactly the dialects that we have taken into consideration, embodying these phenomena. They are spoken all day today. Given this fact and the needs of today's Albanian language, we cannot say that they are sufficiently extended.

We constantly aim their delivery and any typical phenomenon that may come before us, or even casting doubt on the phenomenon discussed earlier, if necessary. But all of this should not be mistaken as a sign of conservatism in linguistics. The dialects vary from day to day and as stated eminent scholar F. Altimari for Albanian and the situation of these idioms "It's good that language evolves and changes as would otherwise have to do with a dead language ...". So all this, and this paper too does not mean that the language should not evolve, but some phenomenon are good explanations and they should be percieved before they disappear. This constitutes the opening of discussions to which we'll talk at the end of this paper.

\section{Paper Review}

Common occurrences of these idioms, apart from the values of sociolinguistics and linguistic character which will also list them at the end of this paper, are indicative of another important phenomenon that characterizes Albanian: Although Albanian frantic sequence and changes in the course of globalization, essentially remains an old language. Occurrences listed below, along with generalizations and relevant analysis (valued in our view), the best prove such a thing.

We initially start with a handle occurrence of us for the first time (Troplini b. 2014). It is about a so-called letter from the arberesh village of "Shën. Palj" (San Paolo) in Cosenza, Italy, then to diagram lj: "Rrofshi, ljulëzofshi e më mos u martofshi": s'është mos një evend i katundit aq i bukur e i ljumtur sa ai kur dy të rinj martohen (...) (Abitante 2013), that is translated:

"Live long, flourish (have children) and not more have other marriages ": there is not such a beautiful and happy event in a village as a young couple get married(...)

There is no question that this is a phenomenon of early Albanian, because, except in our days, it is also found to some old Albanian documents.

In pronunciation, it has similarities with another early Albanian phenomenon located in Cham dialect, namely, the so called strong $\mathrm{H}(\mathrm{X})$ borrowed from Greek. The latter, as we will see below is best analyzed separately. Regarding this phenomena the researcher Niko Stillo has done even more analysis which can be taken into consideration as it distinguishes several types of this letter (Stillo 2011: 88). 
So it comes to two phenomena in writing that they have no communion, while they resemble imposed. We arrive at this conclusion after close observation of these phenomena. Although to reach the correct conclusions from phoneticians are required measurements, so we present the case after its display case.

Incidentally what we found in an earlier phrase served by the writer Martin Camaj found by Ludwig Braun (professor of classical philology at the University of Frankfurt in Germany), as he was preparing scientific publishing of a comedy in Latin of the Venetian author Tomasso de Mezzo (1422-1488). The phrase is Tramburete klofteo golje (Dramburi të clofto goglie transcripted Dramburi të klofto golje). Despite the interpretation of the most prominent scholars of this Albanian phrase mainly to its meaning (Osmani 2009), this phrase immediately reminiscent of today's popular phrase T'u thaftë goja!/ Dry up your mouth! All Albanian speakers (simple individuals, average age of compulsory education) who have tested about the semantics of such a phrase, immediately responded that it was early Albanian. Specifically the question was: What does this mean? The response we received was: This is old Albanian or ancient Albanian or ancient languages, etc.

And, more or less in areas where they had been originated, the explanation revolved around the expression Dry up your mouth! So this is a curse phrase so not only noticed by researchers but also by ordinary people. However what we care within this expression is the word golje, the diagram or letter carrier in question.

In support of this view have also singled out two words from the analysis that the researcher Victor A.Friedman (Llalla 2007), makes the archaic idioms of the villages Arcadia (Greece), Ukraine, Mandrica (Bulgaria), populations who speak Albanian folk, specifically, the Ljupë e Ljutë.

Arcadia: Ljupë, Ljutë

Ukraine: I'ope, l'ot

Mandrica: cows, tears

Standard language: lopë, lot/cows, tears (Troplini b. 2013)

Our curiosity about such a phenomenon does not end here. The questions before us are many:

First: Are we dealing here with a Latin diagram lj? Taking into consideration the Albanian latin borrowed words which are numerous (as far as Meyer called Albanian half a Latin language), it also can stand. On the other hand, the imposition of its pronunciation resembles the letter $(X)$ which is thought to be borrowed from Greek refutes such an assertion.

Second: Are we dealing with a letter lj as St. Palj arberesh's claim? If it comes to the lj of Victor A.Friedman (let's call it), or the lj served by Camaj, or the lj found in the early dictionaries served by Stillo (although he identifies it as a diphthong), as well as for all other cases that will treat below; think that is the case we say that we have identified an old letter of Albanian.

Thirdly, we have simply to do with the diphthongs iu, ia, io etc., when these diphthongs appear not necessarily preceded by a consonant I before. Even here the pronunciation problem appears. What we need to explain is the fact that in all the above cases we harvest it almost to the same words. This detail, as well as the extension of the following examples divest him of being a diphthong.

In order for the reader to understand and to be clear, we are analyzing everything concluded through the analysis of several examples.

Thus the analysis of "Four languages vocabulary" of Danil Voskopojari, Niko Stillo researcher undertakes the treatment of diphthongs (Stylos, 2011: 84, 92). There we will find the diphthongs io, iu, ii, ie, ia.... etc. Although in our view this is not an acceptable interpretation, the treatments that this researcher brings, are very valuable to us because we encounter in "Four languages vocabulary" again this letter, to the same words. We are presenting these examples as researcher has written surely that the examples given are given in defense of his thesis regarding diphthongs, ex.

liùmerat (lumenjtë- the rivers), pliòt (plot- full), liùlete (lulet- the flowers) (f.164); liàkrate ( lakrat- the pot herbs) (f.165); liàrt (lart- on high) (166); liùtzon (lulëzon-flourish) (167); edhe liàkhithi ( edhe lajthiti- and nuts) (f.172); ke te liùtet (që të lutet- that he may pray) (f. 174); kièlia (të paturit - the heaven), po te liès (po të lë- but leave) (f. 182), ke te bliùane (që të bluaj- to grind) (184); buliùare (mbuluarë- covered) (186); liùadhne (livadh- the meadow), te blieths (të mbledhcollect) (190); lièpure (lepur- hare) (192).

Stylo researcher has not taken into consideration the consonant I and has treated all cases together as diphthongs. Perhaps the researcher is not aware of the existence of this letter to arberesh today and we were not even aware of it until we randomly appeared. This is a good case in order to insist more to phonetic, morphological, lexical and especially the syntactic phenomena, (while syntax is little delivered in the speech study, but these dialects provide many in this direction) of these idioms, always within the approximation of these phenomena from a dialect to another, but also to approach quite specific occurrences of each idiom, with other spoken Albanian dialects and documented. 
Proceed with finding other convincing arguments in support of the same thesis. In the text History of Albanology (1497 - 1997) the researcher Jup Kastrati is written about ritual formula of Bellifortis's handwriting. It prevails in our view a word, the word biljat-daughters. According to the author this document (whether to call it) was found by the Assistant Professor at the University of Bucharest Dumitru Todericiu, in 1967, in an act of chivalry of the year 1405. This ritual was read and decomposed, first in English by Demetrius Polena and then studied by Robert Elsie. The latter interpreted as Albanian twelve words: izë, zabel, janë, jonë, rragam, i madh, përbri, afsh, vashëri, ehem (i mprehtë /sharp), biljat /daughters (Kastrati 2000: 40).

So as we see in the XV century Albanian versions are golje (golë-mouth), bilje (bile-daughter). In today Cham dialect have encountered traits as: golë/mouth, bilë/daughter, fëmilë/child. We also know that Robert Elsie has studied very much the dialect of Chameria. And, if you deal with such an ancient dialect, certainly grows the curiosity on oldest Albanian texts day by day.

According to the same researcher (Kastrati), in the same text, we find several other examples about the same phenomenon as the author interprets the image of the Engjëll Mash. The latter is based on Leibnizi (Kastrati 2000:551) So give us some words where there is a doubling of the vowel, which among other things stated length of pronounced vowels as: dhii, deer, druu, njerii, shpii, dhee, deet, guur, heer, puulj/ hen. Doubling the vowel is a phenomenon that we have identified in these dialects and necessarily we are going to retake again. But what about the phenomenon in question is the latest example of which is found to the same phenomenon: puulj. - Ibid, while female names mentioned in the indefinite form, without terminal letter ë, we see again this diagram or letter. Thus we have: buk (bukë/bread), nat (natë/night), bretkos (bretkosë/frog), pem (pemë/tree), drit (dritë/light), diers (djersë/sweat), ljuft (luftë/war), gjum (gjumë/sleep) etj.

According the same researcher (according Kastrati), Engjëll Mash says: "words with y, are written with i: iil (ylli/star), grik (grykë/throat), krie (krye/head), krip (krypë/salt),etc". In this text there are, -he still continues, word forms that are preserved among the Albanians of Italy dialects as: rah (kodër, mal/mountain), bilj (bijë, vajzë/daughter), thron (fron/throne), ruanj (shikoj, vështroj/to see) etj." (Kastrati 2000: 551).

So, as we see here appears the identical phenomenon. While the lack of vowel y will deal below.

While the researcher Kastrati itself reaches the following conclusions: "In two dictionaries of the most conspicuous phenomena Andrea Dara's main phonetic system of the Dialect of Adrian Palac, such as: lack of the phonem -y, the presence of groups of consonants kl, gl; content of consonant groups $\mathrm{pl}, \mathrm{bl}, \mathrm{fl}$ (bluesi/grinder, bleta/bee, pluhur/dust, plakunë/become old, flutur/butterfly); the conservation of vowels group uo (truom, paguonj/pay, t'shikuomit/seeing); presence of long vowels; presence of sound lj: ftuljë (ftujë), diljirë (pure), bljeta (bee). As we see Kastrati labeled as sound, but the sound is not mentioned by anyone then, not even by Kastrati itself.

These examples are exactly those of whom we think this is a phenomenon in itself and can not be treated within a diphthongized.

Having been to diphthongs, now we go to another phenomenon. We are talking about the vowel heap ua which in the old Albanian dialects in question appeared in the form uo. What we have long attracted the attention of another heap in today Chameria dialect, namely inverted ou heap: punou/ work, kalou/went, etc., which is found in some older people, but also to some preschoolers who stay with their grandparents today. So now we have two possibilities of interpretation: first, we simply have to do with a reversed sequence; second, we just have to do with specific dialects within this provincial dialect. However this is a phenomenon in the above observation, more or less as it was originally the diagram, sound or letter lj.

On the other hand, should be studied in order to better differentiate also: specific occurrence of each of the speech (as is characteristic of nasal sounds to Vakarico dialect), of phenomena that are seen as part of physiognomy of regional dialects as a whole (as is the phenomenon of syntactic emphasis on Cham dialect (found in all dialects of Chameria), and of phenomena within these idioms (Arbëresh, Chameria, Arvanit and specific idioms to each of them) that make up their internal developments (that are not ancient character traits). Is already logical that the only rate that the dialects without prestige do respect, is just a known rate thanks to the instinctual agreement between them. Within each ethnic community are inevitable internal developments of idioms. We give some examples of Cham dialect associated with the latter.

In the older Cham generation find some verbs used with the theme in consonant that the plural second-person take several forms to which we think are developments within the Dialect: ju hapi ( ju hapni-you open ), ju merri ( ju merrniyoutake), ju vrisi (ju vrisni-you kill) etc. To this generation also noticed that some verbs in the third person of the perpetrators of the simple take-ending -i: ajo vdiqi (ajo vdiq-she died). This phenomenon is reflected to all generations, including young age. 
For verbs in the simple past that come with suffixes -va,-s (verbs with the theme in vowel), we see that this analogy takes the termination of its third -vi ending namely: bleva, bleve, blevi (bleu/ bought)/ blevëm, blevët, blevën (blemë/we bought, bletë/you bought, blenë/they bought). The same thing happens to other verbs, bëra, bëre, bëri/ bërëm, bërët, bërën (bëmë/we did, bëtë/you did, bënë/they did). This phenomenon is observed more to the generation of new medium and Cham. These are also some typical forms used by young children to any dialect today. They really are regular shapes, but not according to the standard. In today's standard they belong to the so-called area of irregular morphology. So while kids in general, over the years, in a sign of conformism, eliminate these forms of "regular", Cham speakers of new and medium generation don't do such a thing showing individuality in this regard.

In Cham and Arvanit dialect have also noticed some constructions which Klosi (observation and analysis of texts of Reinhold) interprets as constructions that use without: pa të pienj, pa t'e ndiejmë, pa t'e ndogi me vrap, pa t'ia dha të klarit, pa t'e qëlloi. If our interpretation in Arvanit dialect, whether in Cham dialect to shape the type of "without" mainly for purposes of this shape, connected with an adverb of time immediately, instantly (Troplini c. 2012). So the semantics of the above traits is more or less this: të pyes/to ask, now instantly; ta dëgjojmë, tani në çast /l'm hearing now instantly; në çast e ndoqi me vrap/now immediately ran; në çast ia dha të qarit/instantly gave a crying; në çast e qëlloi/shot instantly. Even this phenomenon is also introduced among those phenomena which deserve a specific detailed observation.

Another phenomenon that has long impressed us is the phenomenon of emphaticity of Albanian language to dialects in question. Regarding this phenomenon, many scholars, as it deliver the texts of old, not being in touch with the discourse of these idioms today, erred in determining this trait.

Klosi researcher during Reinhold's handwriting analysis speaks of "life and rhythm of spoken language", to which he thinks has to do with a swinging rhythm of Basil Pater (Reinhold's collector of texts). Distinguished S. Riza linguist speaks to a kind of individual pronunciation of Buzuku while examining the phenomenon of plural in his work. Niko Stylo in Marko Bocari vocabulary ( Stylo 2007) highlights the same as it is for the Albanian emphaticity. While closely examining these idioms, see that this is a feature that is preserved even today. So has to do with early Albanian and not emphaticity or individual pronunciation etc., of the individual itself. The phenomenon that once treated, the emphasis on Cham syntactic, syntactic diversity of some traits specific to this dialect etc. reflect the best the feature of Albanian language as a emphatic language, living and as a language with strong character.

Given the lack of antihiatic $j$ to these dialect specifically to examples (Buzuku the enclitic e with o-verb in the imperative unites it without the antihiatic consonant j: huchoe. In Arvanit dialect we have: shtëpi-shtëpia, qevërri- qevërria, Çamëri- Çamëria, Parmëthi- Parmëthia etj; Hasimea, Gjulea, Fatimea etj; nuse- nusa, dele- dela, lule- lula, maçe- maça etc. Prindi i thotë: "çë më pien? Ashtu më piejti/asked edhe é-ot motrë e madhea, e i-a thashë, e më shaiti/railed: -çë do edhe ti , çë kërkon?), have identified another old phenomenon which relates specifically with the simple past tense in indicative mood. In the example above we see the verbal traits (më piejti/asked), më shaiti (më shau/he railed me). This form is found even in the other two dialects: Arberesh dialect Nuses ng'i pëlqejti përgjegja e krishtit e tha; in Cham are also found forms of e qajti (wept with words-groove), e gajti (e ngau, e ngacmoi/tease, haunted), especially when accompanied by short form e of the accusative. Apparently this form appears more frequently if the verb is associated with shortened form of the personal pronoun.

We present below some other analysis and generalizations about some old typical phenomenon of Albanian.

We first start with the long vowel and lack of -y phoneme, as also mentioned above. Regarding the first (the length of the vowel in Albanian), we observe it closely in defense of the idea that the grasp in Albanian not necessarily prevails only thanks to the phenomenon of emphasis, but to ancient dialects, or in some cases as, depending on the situation, some unit linguistic structure are associated with the discursive structure and the grasp can stand out the long vowel (Troplini d. 2013). We are listing once again the conclusions on the long vowel to see how diverse it is presented in Albanian, although the literary standard does not contain the long vowel.

Foreign scholars for the length of the vowel in Albanian, have managed to find three scale of lengths: the vocal length, intermediate length and the short quantity: Dozon, Manual i gjuhës shqipe, 1879 (Dozon 1870: 179); Pekmezi, Gramatika e gjuhës shqipe, 1908 (Pekmezi 1908: 46); Vaigand, Gramatika e gegërishtes jugore, 1913(Weigand 1913: 05). According to these scholars Albanian has the shortness, semi-length, and vocal length; for example in the word măl (mountain), the "a-" is short; in the word máli (the mountain), the "a-" has an intermediary length... , and full length have the words bār (grass), (barī - herdsman); hatā (havoc); drū (wood) etc. (Ajeti 2005: 225).

In standard Albanian long vowels usually coincide with the accent, but it is not quite the same thing in the dialect or in daily discourse. With such a judgment also Ajeti disagrees (Ajeti 2005: 227), as the author in question takes as an instance the dialect of Gjakova and that of the text of Vehbije previously documented in the Turkish-Arabian alphabet. So, apparently due to these conclusions we can jump to other detalied observations of early Albanian. 
In the northern dialect of Gjakova Prof. Ajeti mentions another length, - compensative length in this discourse and other gheg discourses is obtained in the preceding syllable words, after the ending "ë" drops: ditë- diit- dit (day), pikë-piikpīk (drop), arë- aar- ār (field), borë- boor- bōr (snow), fletë- fleet- flēt (page) etc. The same length Prof. Ajeti notes in the text of Vehbije, the oldest document of Kosovo Albanian written in Arab-Turkish alphabet (Ajeti 2005: 221).

It is still preserved in the most archaic dialects of Albanian (Cham, Arberesh, Arvanit etc.). Examples: tagdiir, undiir, cihuur, buhaar (long vowels before the liquid -r consonant); the future of the past and the pending (its third) union of two identical vowels has taken the form of a diphthongized in which the semivowel $i$ is present: do vii, i shpii bukën, $i$ lii diçka (here we have to do with the semivowel i); the conservation of long vowels in open grasps (dhe: , gra: , shpi: , shi:, etc.) and closed grasps (bi: r, mi: r, shka: I, pa: I etc.). The conservation of long vowels at Buzuku : a: Chaa meh chleneh 188/31; baasi 4b28; teh paah lih tatti tpaemenit 29b42 etj;e: aih teh formonee 12b45; Galileesse 11a29; teh

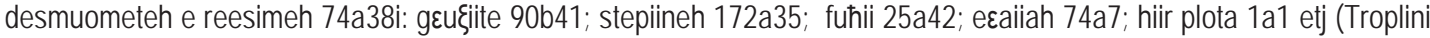
e. 2009).

All these examples indicate the long vowel diversity and its presence in Albanian today.

Proceed with other phenomena which have treated within the approximation of the ancient dialects (Troplini c. 2012), but in defense of the thesis of this paper think to remind them again, along with some of the generalizations and valuable analysis that we have reached for each of them.

- Lack of -y phoneme and the use of the phoneme i in its place. Even this is an early phenomenon, for whose preservation to these dialects has been spoken separately, but not in the context of alignment with each other. This phenomenon appears in our view the most archaic in Cham dialect. To the dialect of Arvanites (analysis by Klosi), and to some Arbëresh idioms, sometimes appear the vowel -y. The same thing happens to "the dialect" of Leake (Hoxha 2007 ). Examples: jo ata ta ç hin për gojë pëgan nierinë, por ata qish del; i tire, (i tyre/their), lier (lyer/dyed), drise (ndrishe/ ndryshe-different); drishe, ill (yll/star), krie (krye/head) si edhe këture, i ture; sutë emii ( $y>u) \ldots$ etc.

- Groups of consonants kl, gl. By the analysis that we have done especially to this phenomenon, it is clear that it shows greater conservation in Cham. As in Gheg, even among some Arbëresh dialects, these groups are reduced. Even to the dialect of Arvanites (to analysis by Klosi sometimes they appear as today in Albanian). Examples (Troplini a. 2012): i glatë (i gjatë-long), endiglo, gluhë (gjuhë-tongue), clissë (kishë-church), klai/ klanjinë (qajnë-cry), glunjë (gjunjë-knees), kle- (qe-were), kleçë (qeshë-was), glisht ( gisht-finger), klumusht (qumësht-milk), kliçe (kyçe-joints), glëmbi (gjëmbi-thorn), i shklier (i shqyer-torn),i shklarë (i shqarë- i shkarë, i çmendur/mad), klishë (kishë-church) ...etj.

- Conjugation verbs in mi, mostly the verbs to be and to have. Early forms of these verbs are unquestionably noticed in the dialects in review. It is specifically for the forms: jesha (isha-I was), jeshe (ishe-you were), ish ( ishte-he was) / jeshëm (ishim-we were), jeshët (ishit-you were), ishnë (ishin-they were); kesha (kisha-I had), keshe (kishe-you had), kish (kishte-he had)/ keshëm (kishim-we had), keshët (kishit-you had), kishnë (kishinthey had); kleva (qeva-qeshë/was), kleve (qeve-qe/was), kle (qe/was). They matched the traits of Buzuku (remember - the first written document in Albanian): ish ardhunë, klenë ardhunë, ishnë ardhunë, kle ndekunë, keshe lenë, i kish ardhunë, mos keshë thanë etj.With regard to these forms can say that, forms kleve, kleve, kle mainly represent innovation to the dialect of Chameria, while forms jesha, jeshe, ish/ jeshëm, jeshët, ishnë; kesha, keshe, kish/ keshëm, keshët, kishnë represent innovation to two other dialects: Arvanit and Arbëresh (of course these innovations reflect one or the other dialect depending on the respective idiom of the respective villages. For a more accurate recognition of them you may see recordings of the speech today in the online journal "Jetë Arbëresh").

- The traits of sigmatic aorist. In Buzuku speech we do have: u mbeç( unë mbeta-I remained) me ta 23a9; u Gjoni gjegjsh (dëgjova-I listened), u di kaha erdhshë (erdha-I arrived)87b31; ù paçë (pashë-ı saw) pësuotë 174a45; u gëzuoshë (u gëzova-I was glad), u mplakshë (u plaka-I am old), u rrëfyeshë (u rrëfëva-I confessed), $u$ bashë ( $u$ bëra-I made) etc. In the three other dialects (Arbëresh, Arvanit, Cham) have respectively the forms: i thaçë (i thashë-I told), ia thaçë ù, t'e thaç ù më parë, do viç (do të vish-you are coming) me mua; do të shkruaç (do të shkruash-you will write) ti; do t'inçizoç (do të inçizosh-will record); u bëç (u bëra-I made), u mplakç (u plaka-I am old), u merruaç (u tmerrova-I was terrified), u lodhç (u lodha-I am tired), u poqç (u poqa-I was roasted) n'diell etc. Sometimes in these idioms they are used in the form u dogjsh, u poqsh, u zushë etc.

- $\quad U$ trait of the personal pronoun me. Associated with such a form of historical grammar ( Likaj 2000) have learned that early forms of -ù is derived from a personal pronoun "swe" of the indo europian language. In the first sentence of the text of Buzuku we have "Ù don Gjoni i biri i Bdek Buzukut ....etc. For consistency we give 
out a sentence for each idiom; Arvanite (Reinhold): "tatë, po të të shanj, si ato, s'jam vaiza é-otë": - uratënë t'ëndë edhe tri të véshura burrërishte: e ù (unë-me) véte prë ti."; çamërishte (Troplini a.c. 2012): në saba grihet u thotë babajt e nanës/ kam parë një nëndër u (unë-me) tha/ thuejna i thanë ata/ nuk ua thom//

- Suffixes of non active verbs. Even this is an ancient phenomenon that distinctly stands out. In Buzuku we have: ù nçonem (unë çohem-I stand up) 69b8, a do të pagëzonesh (do të pagëzohesh-you will baptize) 34b6, ai...qi ndë muo mos skandalixonetë (skandalizohet- scandalised) 38a7, porsi kthenetë (kthehet-to turn) torrenti5b45, a nukë shihni se gja nukë shumonemi (shumohemi- multiply); banemi (bëhemi-to do), kthenemi (kthehemi-turn), shkurtonenë (shkurtohen-shortened) etc. Also in these dialects we have: vineshin (vinincome), bënej (bëhej-to make), martonej (martohej-marry), rregulloneshin (rregulloheshin- were regulated), shtroneshin (shtroheshin- were taken up), pajtoneshin (pajtoheshin- agreed) do not hesitate to present some verses in Arvanite dialect: "piete ani, ç'bënetë (ç'bëhet- what is done)/ me turqit atje, me qentë/t'i ketë a mos t'i ketë/ndë pisë thellt' e më thelltë/ që na cfilitënë dreqtë!"

- The conservation of I sound in words like: fëmilë (fëmijë- child), bilë (bijë- daughter), kuel, kuelj(kuaj- wail), rrumulë (rrëmujë- mess), milë (mijë- thousand), palë, paal, (pajë- dowry), valë (vajë- wail), golë (gojë- mouth) etc.

- Melting short traits to the three dialects as: t'e marr (ta marr- pick), t'e shoh (ta shoh- see), t'e hajë (ta hajëeat): E vërteta ngë mund thuhet, pse mosnjari do t':e gjegjinj (do ta dëgjojë- will listen).

- Some common forms to some specific verbs like: vata (vajta), pava (pashë): ù vata, ti vate, ai/ajo vati ; ne vatëm, ju vatët, ata/ ato vatën; ù pava , ti pave, ai/ajo pavi; ne pavëm, ju pavët, ata/ ato pavën. Djali vate (vajti- shkoi/went) ne kali në katua prapë (...) vanë (vajtën- shkuan/went) prapë në kufi të bukrës dheut /I (Cham tale)

- Shortened forms of participle u ka bënë equivalent with the form është bërë.

- Conservation of neutral gender: të parët, të klarët (të qarët/crying): Plasi ka të klarët

- Stand out affricate consonants in words like: xathur (zbathur-barefoot), maçe( mace-cat), xheshur (zhveshurnaked), xë (nxë, mësoj-learn), xëj (nxë-caught); pse e xore (nxorre- bring) në mejdan ti i tha kali/ më pa kur bëra duhan / mos u sellkëdis $i$ tha kali (the same tale) etj.

- The conservation of the strong $\mathrm{H}(\mathrm{X})$ borrowed from Greek (a unique and controversial phenomenon, as there are scholars who say that the Greeks may have borrowed it from the Arabic): axere (atëhere-then), rrijëm në xje (hije-shadow) t'ullinjve. In Arvanite this phenomenon is found once with $x$ and once with ch while in terms of Arbëresh, we think that $/ \mathrm{gh} /$ sound, in words like: ghare (hare, gëzim-gaiety), shogh (shoh-see), bëghem (bëhem-become) (Solano), can be related with the same sound.

- In all dialects, including the dialect of Buzuku are noticed some common lexical obsolete words as: Gjegj, (dëgjoj-listen), botë (dhe-soil), glas (ngas-drive), klënë (qënë-were), psonj, mbsonj, mbsonj, mpsuaritë (mësoj-incur), sherti, sherëti, sherëtinj (psherëtij-whisper), ù (unë-I), u-ja (urija-hunger), vetëhe (veten-myself), jatri (barë, ilaç-medicine, but in Cham we also have jatro, mjek-medic), kurm (trup-body), pisë (i zi sterr- jet black).

- The conservation of the participle (bëj-to do) in the form bënë: kish bënë (kishte bërë-has done), ish bënë (ishte bërë-has been done) etc. Even the intermediate Cham generation uses: e ka bënë (e ka bërë-he has done), u ka bënë (është bërë-it has been made).

- A separate issue constitutes the treatment or Turkish and Greek borrowed words to these idioms. ...Etc.

\section{Discussion}

Then the question arises: Who are the factors that stimulate their conservative character? Sure, a crucial role play the out linguistic factors as much as:

a- The mechanical movements time after time of these populations.

$\mathrm{b}$-The way of integration of these people in the receiving communities.

c- Psychological factor of displacement; the great love for the nation which can't motivate the loss of language as its symbol. This factor is felt early in the early Arbëresh diaspora (for such a fact also speaks the literary language), who even though have gone away by their will, have gone away to national issues. Even in Cham population occurs the same phenomenon.. They were subjected to ethnic cleansing. Even today they miss their ancestral land and their territories. To say nothing then to Arvanites who have always been deprived of the language of their nation. Language is exactly what 
identifies these people as a community of humble and very tired. The spiritual conservation unquestionably leads to all these dialect, to all generations.

At this stage of the paper we return once again on the generalizations that Gjinari makes about the speech: dialectal words leave their place to literary language features, or take place in it. (Gjinari 1985: 45).

Of course all the above phenomena treated as conservative are found in specific words of idioms or "are connected with parts of the system" and therefore, should have been the first to be withdrawn in front of the literary variant, but in such dialects, they will always remain a substrate of archaic words. Consequently, we join Prof. Shkurtaj opinion that "there is no lexical development itself for itself, but transformations and conscious stratifications caused by the growing needs of speakers to impart. But on the other hand, we think that this statement is more concrete for the older generation. Continuing the thought, Shkurtaj thinks that ... the speaker, because the expansion of the proclamation and already according the more qualitatively social circumstances and the environment where the communication is performed, lines with full awareness of the close dialectal form of words and prefers those with a wider range ... (Shkurtaj 2009: 38), on the other hand think that warranted more for the younger generation. While talking to the intermediate generation, would be to use once again one assertion after another, because the dialect is characterized by a kind of equilibrium between the two dialect generations extreme dialects (Troplini a., 2012). However in this kind of withdrawal, change wins, and orientation towards language with greater prestige as the official language standard is (Shkurtaj 1981). Although preservative, bias towards standard is noticed even in the older generation. This is a phenomenon to be ignored if we consider the years of standardization of the Albanian, but is a chain phenomenon that will always happen generation after generation.

So labeling "conservation idiom" cannot exclude the change, their development and renewal, more so if it is is such idiom which have been continue and will continue to be for a long time and such a thing can be understood thanks their conservation to the desire of fanaticism times, once with love and perseverance. On the other hand, they have been, and will continue always to be under the effect of a continuous change, renewal and of unquestionable renovation, processes that are not only inevitable in all dialects, but in the situations of languages (or dialects) in contact, are the inevitable result of a continuous bilingualism.

I believe that the idioms themselves develop these two opposite poles, so conservation and innovation at the same time and we think that is the very reason of their survival until today.

\section{Conclusions}

Regarding linguistic phenomena addressed above, as well as all other common phenomena among the speeches in question, certainly not the last word is said, also to the fact that we have not disbursed all of them. So they are even more varied. In this paper we have extended those phenomena that stand out more for their preservative character and features of the Albanian today. We do know also that such occurrences think to commit one by one in separate papers for each. Phenomena in question have special significance for our language of old and new, to achieve some valuable conclusions as:

1. The sociolinguistic and dialectical value that these dialects have. The data, the features of these dialects are considered quite valuable in the dialectal context of the sociolinguistic situation of Albanian language.

2. The indisputable link between sociolinguistics and language history. Archaic dialects of Albanian today are becoming evidence not only for its surpassed stages, but through them are also revealed quite historic character issues. Conservation is a helpful factor to these dialects that should be perceived before they disappear in the future. In the context of a later documented Albanian and all the still unsolved problems of the historical aspect of language and for the values that still carry these idiom, we should anticipate this risk.

3. Conservation is a feature that unites completely all lateral dialects on a common denominator and the spiritual conservation (own conservation strength, that demonstrate the strong Albanian character of these residents) leads to the idioms in all generations.

4. These dialects create numerous approach opportunities.

5. Within studies: new with the old, through these idioms drawing conclusions about the report "regional dialectthe official dialect". The strength that characterizes the Chameriadialect, the Arvanite dialect or the dialect of Albanians of Italy (Arbëresh), is on the one hand,-preservation, conservation and in turn, the development of these idioms under pressure of linguistic factors and out linguistic factors towards the prestige language, but this development is characterized by a slow pace. 


\section{References}

Abitante, P. Paper, International Symposium on Bilingualism, Languages, Cultures, Literatures, and Local and Immigrants' Identities, ISBIL 2013, Sibari (Kalabri), 06-08 Settembre 2013.

Ajeti, I. Studime dialektore dhe etimologjike, Akademia e Shkencave Shqiptare, Tiranë , 2005.

Bellusci, A. Gli arbërori- arvaniti, un popolo invisibile (Ricerche etnografiche nell' Elade,- 1965- 2000), Cosenza 2004.

Berruto, G. 1994. Sociolinguistica, Bologna (reprint of 1974-es)

Gjinari, J. Marrëdhëniet e sotme të gjuhës letrare me dialektet (Today's relations with the literary language dialects), S.F , nr.1, 1985 Haxhihasani, Q. Vështrim për të folmen e banorëve të Çamërisë, "Dialektologjia Shqiptare", vëll.I, Tiranë 1971, vëllimi II, Tiranë 1973 Hoxha, Sh. Kontributi i Uilljëm Martin Likut në fushën e studimeve albanologjike, Prishtinë 2007.

Hudson, A. R. Sociolinguistika (translated into Albanian by Mariana Omeri), Tirana 2002

Jetë arbëresh - Revistë shkencore (On line)

Kastrati, J. Historia e Albanologjisë (1497- 1853), Tiranë 2000

Klosi, A: Netët Pellazgjike të Karl Reinholdit (Old albanian greek texts collected by Carl Reinhold 1850-1860, (K\&B), Tiranë, 2005

Llalla, A. Arvanitasit - Çamët në etnikumin shqiptar në Greqi (arvanitasit themeluesit dhe drejtuesit e Greqisë moderne 1821-2005, International Symposium, 16-23 settembre, Tetovo 2007

Osmani, T. "Me rastin e 547- vjetorit të formulës së Pagëzimit (1462), -rreth dokumenteve të hershme të shkrimit shqip", Malësia 2009

Reinhold. C.H.T. Këngë popullore të arbëreshëve të Greqisë "Mbledhës të hershëm të folklorit shqiptar", Instituti i Folklorit, 1961.

Riza, S. "Gjon Buzuku (1555)", Pesë autorët më të vjetër të gjuhës shqipe,- krestomati thjesht gjuhësore, Tiranë, 1961/ 66

Solano. F. I dialetti albanesi dell' Italia Meridionale, I, 1979

Stylo, N. Fjalori katër gjuhësh i Danil Voskopojarit, Tiranë 2011

Stylos, N. Fjalori i Marko Boçarit, Tiranë, 2007.

Shkurtaj, Gj. Ligjërimet arbëreshe (shqyrtime dialektologjike dhe sociolinguistike në ngulimet arbëreshe të Italisë), Tiranë, 2006.

Shkurtaj, Gj. Sociolinguistika shqiptare (Albanian sociolinguistics), SHBLU, Tiranë 2009.

Shkurtaj, Gj. Vëzhgime mbi shtresat leksikore dialektore dhe letrare në të folmen e Lezhës, në "St. fil." 3, f. 1981

Troplini, E. c). Some approaches between Cham, Arbëresh and Arvanitika within the standard literary language. (Disa përqasje midis çamërishtes, arbërishtes dhe arvanitishtes në kuadër të gjuhës së sotme standarde), Università "La Sapienza" di Roma, 2012

Troplini, E., d.) La sillaba, tra le strutture linguistiche e strutture sociali (Rrokja ndërmjet strukturave gjuhësore dhe strukturave shoqërore), 11-13 Aprile ( La sillaba:stato dell'arte e prospettive), Università degli Studi di Chieti-Pescara, 2013

Troplini, E., a.) Çamërishtja dje dhe sot, Doktoraturë, Tiranë 2012 (The cham dialect of the past and today, "Dialectological, etnolinguistic and sociolinguistic studies of written and spoken Albanian language of Chams" Doctorature, 2012)

Troplini, E., b) Vlera sociolinguistike e të folmeve të hershme të diasporës shqiptare në Europë. (Sociolinguistic value of the dialect of the Albanian diaspora in Europe), Seminar of Albanology, Tetovo 2013, Macedonia.

Troplini, E., e.) Disa bashkëpërkime gjuhësore të veprave më të hershme shqipe me çamërishten e sotme (Concordances of linguistic elements of earlier Albanian works with today Cham dialect), International conference of Scientific Institute "Alb-Science" (Fourth meeting ), Tetovo, 2009, Tetovo, Macedonia. 